\title{
Natural and Instructional Input Practices: \\ Consciousness-Raising in ELT
}

\author{
Mona Hassanzade \\ Department of Foreign Languages, Kerman Branch, Islamic Azad University, Kerman, Iran \\ E-mail: mona.hasanzade@yahoo.com
}

Mehry Haddad Narafshan (Corresponding author)

Department of Foreign Languages, Kerman Branch, Islamic Azad University, Kerman, Iran

E-mail:mnarafshan@yahoo.com

Received: January 2, 2016 Accepted: February 10, $2016 \quad$ Published: February 11, 2016

doi:10.5296/ijele.v4i1.9006 URL: http://dx.doi.org/10.5296/ijele.v4i1.9006

\begin{abstract}
Many researchers on language acquisition agree that early onset is important when acquiring a second language (L2). Second language acquisition depends on the experience of the target language. Accounts of successful L2 acquisition have accordingly emphasized the importance of the quality of the input available to the learners. Consequently, this study probes the impact of input quality on second language grammar comprehension and production of young children. 40 infants ( 3 to 4 years old) were selected as the sample of this study. The results revealed that explicit input which draws learners' attention to linguistic form and structure caused a better grammar comprehension and production in young children; explicit grammar instruction can serve to speed up both grammar comprehension and production process.
\end{abstract}

Keywords: natural input, instructional input, grammar comprehension, grammar production 


\section{Introduction}

Many researchers on language acquisition agree that early onset is important when acquiring a second language (L2).Second language acquisition depends on the experience of the target language. Accounts of successful L2 acquisition have accordingly emphasized the importance of the quality of the input available to the learners.

Language is the most powerful tool in the development of any human being. A good grasp of language is synonymous with a sound ability to think. In other words, language and thought are inseparable (Vygotsky, 1986). Language has a major role in supporting children's process of identity formation and helping them understand where they fit in the new environment they are entering. The acquisition of language is essential not only to children's cognitive development, but also to their social development and wellbeing. Cook (1996) stated that "Language is the centre of human life" (p.1). People learn a second language used as a means of communication among the speakers of other languages (Harmer, 2001).

Learners rely on a combination of experience-independent and experience-dependent mechanisms to extract information from the environment. The role of language input has been supported by different language learning theories, there has been some degree of disagreement in the field of language acquisition between those theories that attribute a small or no role to language input and those attributing it a more central role. As a matter of fact, theories of SLA attach different importance to the role of input in language acquisition process but they all admit the need for language input. In many approaches to SLA, input is considered as being a highly essential factor while in other approaches it has been neglected to a secondary role (Ellis, 2008).

Nevertheless, it has been widely accepted that language input provides the linguistic data necessary for the development of the linguistic system. The concept of language input is one of the essential concepts of SLA. In fact, no individual can learn a second language without language input of some sort (Gass, 1997). One of the essential theories of language learning which plays an important role in SLA research is the input hypothesis established by Krashen (1981). The input hypothesis claims that for SLA to take place, language learners are required to have access to a type of language input which is comprehensible. For Krashen, the only causative variable in SLA is comprehensible input.

The role and efficacy of instruction in second language development have been a recurrent issue of great importance. L2 researchers are not in agreement with regard to the potential role and effect of L2 instruction in second language development. Some researchers adhere to what Long and Robinson (1998) called the noninterventionist position and see no role for L2 instruction beyond the provision of a conducive environment for second language acquisition (SLA) (e.g., exposure to comprehensible input). (Krashen, 1985, 1994; Schwartz, 1993). Others assume that L2 instruction is beneficial for second language development and adhere to an interventionist view (e.g., Ellis, 1997, 2001, 2005; Long, 1988).The second position concerning the effectiveness of L2 instruction has over the years gained extensive empirical support from different types of instructed SLA research (Ellis, 1994, 1997, 2001, 2002; Norris \& Ortega, 2000). Norris and Ortega (2000) in their meta-analysis of 49 studies 
indicated that L2 instruction makes a difference and, furthermore its net effect is substantial, so that "L2 instruction can be characterized as effective in its own right" (p. 480). On the one hand, there are researchers like Krashen (1993) who have persistently denied the importance of any explicit grammar instruction in second language acquisition.

To implement input-based instruction more pertinent to the study is to manipulate the input in some way in order to make some target features more noticeable to learners. The type of input-based instruction usually takes the form of textual enhancement or input enrichment. Both techniques can be considered as focus on form instruction because they aim at drawing learners' attention to linguistic targets while they are primarily engaged in meaning comprehension. Long (1991) conceptualized focus on form as a kind of instruction that “overtly draws students' attention to linguistic elements as they arise incidentally in lessons whose overriding focus is on meaning or communication" (pp. 4-5). The interest in focus on form instruction (also known as form-focused instruction) was raised in 1990s as a result of research findings suggested that exposure to input alone though necessary is not enough and some kind of formal intervention is needed for learners to reach advanced levels of target like competence( Rassaei,2012), Krashen (2003) claimed that cognitive development, including the acquisition of concepts and facts, is more likely to occur through problem-solving than through deliberate study. It is a confusion of cause and effect to teach facts and thinking skills in order that students may then solve real problems. Instead, it is the case, Krashen said, that learning is the result of working on real problems (Ellis,2008).

The significance of input, namely meaning-bearing linguistic instances of the target language (TL) (VanPatten, 1996), in accounting for how learners create second language (L2) grammars has long been established (Gass, 1997). Krashen (1985), in his Input Hypothesis, even argued that the sheer provision of abundant comprehensible input would be "necessary and sufficient" for second language acquisition (SLA). In light of such characteristics as "lack of success" and "the importance of instruction" in Bley-Vroman's (1989) Fundamental Difference Hypothesis adult L2 learners, however, it appears that manipulating aspects of learning conditions may facilitate L2grammar acquisition. Some researchers (Sanz \& Morgan-Short, 2005) suggested that external manipulation of input through textual (Jourdenais, Ota, Stauffer, Boyson, \& Doughty, 1995) or prosodic (Leeman, 2003) enhancement, or even input flood (Trahey \& White, 1993) might induce internal processing, considering that the target forms are made more salient and are thus more likely to be detected by the learner.

Although the role of input in L2 acquisition is increasingly attracting researchers' interest, the role of input quality in second language (L2) acquisition is subject of much debate. One of the major problems in the field of English language teaching is that learners should be exposed to natural or structured input. The role of input quality in second language (L2) development has long been a highly controversial issue in the field of L2 learning and teaching, particularly concerning the procedural use of the language. L2 processes are often discussed in terms of the distinctions between implicit/explicit knowledge, implicit/explicit learning and implicit/explicit instruction. 


\section{Macrothink \\ International Journal of English Language Education \\ ISSN 2325-0887 \\ 2016, Vol. 4, No. 1}

This study tries to answer the following questions:

1. What is the effect of input quality on grammar comprehension and production of young children?

2. Which input (instructional or natural) is more effective in second language grammar comprehension and production of young children?

\section{Theoretical Framework of the Study}

Krashen maintained that second - language learners have at their disposal two distinct and independent ways of developing competence in a second language: acquilsition, which is ' a subconscious process identical in all important ways to the process children utilize in acquiring their first language' (1985, p.1) and learning, which is 'a conscious process that results in "knowing about" language' $(1985, \mathrm{p} .1)$.According to Krashen "learners' fluency in L2 performance is due to what they have acquired, not what they have learned " (1981, p . 99). Subconscious acquisition is separate from conscious learning and is superior in the long run.

Krashen believed that there is no fundamental difference between the way one acquires the first language and the subsequent languages. He claimed that humans have an innate ability that guides the language learning process. Infants learn their mother tongue simply by listening attentively to spoken language that is (made) meaningful to them. Foreign languages are acquired in the same way (Krashen, 2008).

\section{Review of Literature}

Krashen claimed that second language learners have two means for internalizing the target language. The first is "acquisition" a subconscious and intuitive process of constructing the system of a language, not unlike the process used by a child to "pick up" a language. The second means is a conscious " Learning " process in which learners attend to form, figure out rules, and are generally aware of their own process. According to krashen, "fluency in second language performance is due to what they have acquired, no what they have learned" (1981, p. 99). According to krashen (1984, p. 61), comprehensible input is "the only true cause of second language acquisition. "The Input Hypothesis claims that an important condition for language acquisition to occur is that the acquirer understands (via hearing or reading) input language that contains structure a bit beyond' his or her current level of competence (Brown, 2014).

There is an important distinction made by linguists between language acquisition and language learning. Children acquire language through a subconscious process during which they are unaware of grammatical rules. This is similar to the way they acquire their first language. They get a feel for what is and what isn't correct. In order to acquire language, the learner needs a source of natural communication. The emphasis is on the text of the 
communication and not on the form. Young students who are in the process of acquiring English get plenty of "on the job" practice. They readily acquire the language to communicate with classmates. Language learning, on the other hand, is not communicative. It is the result of direct instruction in the rules of language. And it certainly is not an age-appropriate activity for young learners. In language learning, students have conscious knowledge of the new language and can talk about that knowledge. They can fill in the blanks on a grammar page. Research has shown, however, that knowing grammar rules does not necessarily result in good speaking or writing. A student who has memorized the rules of the language may be able to succeed on a standardized test of English language but may not be able to speak or write correctly.

Krashen makes a distinction between natural and instructional input:

Krashen defines natural input as developing competence by using language for real communication. It is the natural way, paralleling first language development in children and refers to an unconscious process that involves the naturalistic development of language proficiency through understanding language and through using language for meaningful communication.Instructional input; however, refers to formal knowledge of a language. It is the process in which conscious rules about a language are developed. It results in explicit knowledge about the forms of a language and the ability to verbalize this knowledge. Formal teaching is necessary for "learning" to occur, and correction of errors helps with the development of learned rules.

Corder (1967) made an important distinction between what he called input and intake .Input refers to what is available to the learner, whereas intake refers to what is actually internalized (or , in Corder's terms , "taken in") by the learner. Anyone who has been in a situation of learning a second/ foreign language is familiar with the situation in which the language one hears is totally incomprehensible, to the extent that it may not even be possible to separate the stream of speech into words. This is input, because it is available to the learner; it is not intake, because it goes in one ear and out the other, and it is not integrated in to the current learner - language system. This sort of input appears to serve no greater purpose for the learner than does language that is never heard. Conceptually, one can think of the input as that language (in both spoken and written forms) to which the learner is exposed (Gass, Behney \& Plonsky, 2013).

Krashen (1985) saw research on the effect of exposure to a second language as support for the input Hypothesis. Studies show for example, that the longer people live in a country, the more proficient their language - unless they live in immigrant communities where they use the second language relatively little and rely on their first language (Mclaughlin, 1978).

The results are somewhat mixed; Loshcky (1994) found that the type of input had no effect on acquisition. Ellis and He (1999) also reported no difference between learners receiving promodified and interactionally modified input. However, Ellis, Tanaka and Yamazaki (1994) found that interactionally modified input was superior to both baseline and premodified input. Two factors can explain these different results. First, in Loschky's study (but not in the other studies) the items were first presented to the learner before listening to the descriptions. This 
may have eliminated the need for modified input to make the items salient. Second, in Ellis and He the time taken to complete the task in the premodified and interactionally modified conditions was controlled and therefore the same whereas in Ellis, Tanaka and yamazaki the interactionally modified input took longer. It can be concluded, therefore, that interactionally modified input took longer, we might conclude, therefore that interactionally modified input benefits acquisition when (T) the items are not first presented to the learners and (2) it results in more time on task and more input - as would be the case, perhaps, when a task is performed naturally in this condition (Lust, 2006).

Processing instruction makes use of structured input but cannot be equated with it. Structured input differs from enriched input in that it presents learners with input in a context that requires them to demonstrate that they have correctly processed the target structure for meaning. The demonstration takes the form of a learner response to an input stimulus, with the response being either non - verbal (for example, choosing the picture that matches the stimulus) or minimally verbal (for example, indicating whether they agree / disagree with some statement). This is achieved by means of "interpretation tasks' (Ellis, 1995a).

The role and efficacy of instruction in second language development have been a recurrent issue of great importance. L2 researchers are not in agreement with regard to the potential role and effect of L2 instruction in second language development. Some researchers adhere to what Long and Robinson (1998) called the noninterventionist position and see no role for L2 instruction beyond the provision of a conducive environment for second language acquisition (SLA) (e.g., exposure to comprehensible input) (Krashen, 1985, 1994; Schwartz, 1993). Others assume that L2 instruction is beneficial for second language development and adhere to an interventionist view. (e.g., Ellis, 1997, 2001, 2005; Long, 1988).

There is a tension between discourse that is appropriate to pedagogic goals and discourse that is appropriate to pedagogic settings. Studies have shown that natural discourse occurs rarely in the classrooms (Ellis, 2008). The teacher's control over the discourse in the main reason given for the prevalence of pedagogic discourse. Some researchers (Gremmo, Holec, \& Riley, 1978) argued that in the classroom setting discourse, rights are invested in the teacher. It is the teacher who has the right to participate in all exchanges, to initiate exchanges, to decide on the length of exchanges, to close exchanges, and to include and exclude other participants. When teachers act as "informants" or "Knowledge "(Corder, 1977b), they are likely to make full use of their rights, and as a consequence the learners are placed in a dependent position. As a result, there is a preponderance of teacher acts over student acts because teachers open and close each exchange. In the opinion of some, pedagogic discourse constitutes a "falsification of behavior" and a "distortion" (Riley, 1997), but other researchers see it as inevitable and even desirable (Edmondson ,1985 \& Cullen, 1998).

Long's general conclusion was that "there is considerable evidence to indicate studies suggested instuction does make a difference" (1983c, p. 374). He claimed that the studies suggested that instruction was advantageous (I) for children as well as adults, (2) for both intermediate and advanced learners, (3) irrespective of whether acquisition was measured by means of integrative or discrete - point tests, and (4) in acquisition - rich as well as 
acquisition - poor environments(Ellis, 2008).

Long, in his original review, claimed that this conclusion was damaging to krashen's position on FFI (i.e. the zero position). Krashen (1985) responded by arguing that the studies did not in fact show an advantage for formal instruction per se ,but only that learming in a classroom was helpful for "beginners", who found it difficult to obtain the comprehensible input they needed in normal communication outside the classroom. In this respect, it should be noted that Weslander and Stephany (1983) reported that it was the beginners who benefited most from formal instruction in their study. To protect himself against Long's conclusion that the studies also showed FFI was advantageous for advanced learners, Krashen argued that the subjects in some of the studies had been wrongly classified as "intermediate" and "advanced". In a response to this, Long (1988) pointed out that his other main conclusions were also problematic for the input hypothesis and that the conclusion that Krashen himself had reached in an earlier paper was, in fact, the right one - "formal instruction is a more efficient way of learning English for adults than trying to learn it in the streets' (Kreshen ,Jones, Zelinski, \& Usprich 1978, p. 260).

The position concerning the effectiveness of L2 instruction has over the years gained extensive empirical support from different types of instructed SLA research (see reviews in R. Ellis, 1994, 1997, 2001, 2002; Norris \& Ortega, 2000). For example, Norris and Ortega (2000) in their meta-analysis of 49 studies indicate that L2 instruction makes a difference and, furthermore its net effect is substantial, so that "L2 instruction can be characterized as effective in its own right" (p. 480).

Some theoretical arguments have also been presented regarding the indispensability of L2 instruction for successful language development for some types of L2 learners, for some non-salient features, and for functionally redundant aspects of grammar (DeKeyser, 2000; Doughty, 2003). In addition to the theoretical significance, the study of L2 instruction has practical importance as well. Its practical importance follows the assumption that a better understanding of the nature of instruction on SLA may lead to improvements in second language teaching practices (Spada \& Lightbown, 2002). Whatever the case for L2 instruction may be, according to de Graaff and Housen (2009), the position of most researchers is that SLA is a process which can be influenced by instruction, though not necessarily at libitum, and it is exactly this relative openness of SLA to instruction which has to be explored, so that it can be exploited for both theoretical and practical purposes (p.727).

According to a study by Ebsworth and Schweers (1997, p. 252), one of the teachers interviewed in the study observed, "It would seem that many practitioners have come to believe that individuals whose goal is to develop excellent English for use in academic or business environments can achieve greater accuracy and control though some measure of grammar instruction." Schneider (1993) and Hunter (1996) showed that learners who received explicit grammar instruction performed well on both discrete-point grammar tests and tasks which draw learners ${ }^{\text {ee }}$ attention to grammatical features.

Wang (1999), in his research into student and teacher attitudes towards grammar instruction in Taiwan, found that students preferred the explicit method of instruction and that most 
participating teachers also favored and used the explicit method in their classes.

Borg and Burns (2008) investigated the beliefs and practices of 176 English language teachers from 18 countries about the integration of grammar and skills teaching. The teachers expressed strong views about the value of inductive grammar learning and strong beliefs in the need to avoid teaching grammar in isolation.

In a study surveying the perceptions of preparatory and secondary school EFL teachers (about 220) and students (about 1,050) from three different geographical regions in Oman, Al-Kalbani (2004) found that students showed a more favourable attitude towards grammar instruction than teachers and that students favoured explicit instruction, while teachers favoured implicit instruction.

In a qualitative research project investigating six middle school English language teachers' beliefs and practices related to grammar and grammar teaching, the participants believed that grammar instruction is necessary to increase students' performance on standardized tests and both traditional and innovative methods of grammar instruction are valuable (McClure, 2006). In a study on teachers' opinions and attitudes towards grammar teaching and their current practices, Petraki and Hill (2010) have reported that teachers use a combination of grammatical theories in giving explanations of grammar rules, because they believe that a variety of grammatical theories should be part of teachers' pedagogical content knowledge.

Akakura (2012) studied effects of explicit input and implicit input on explicit and implicit knowledge of generic and non-generic English articles. Participants received instruction on English articles through CALL activities and their explicit and implicit knowledge of articles was tested immediately. And six weeks after treatment using elicited imitation, oral production, grammaticality judgment, and meta-linguistic knowledge tests, result showed that explicit instruction had durable effect on implicit knowledge and ungrammatical items of explicit knowledge.

Herna'ndez (2011) studied combined effect of explicit instruction and input flood and input flood alone on the use of discourse markers through narration of an event. Ninety one fourth semester learners of Spanish were divided into three groups of explicit plus input flood, input flood and the control group. The EI plus input flood group received explicit explanation on discourse markers as well as feedback on their use of these markers during communicative task performance. The Input flood group did the same communicative activities as EI plus input flood group, but without rule explanation and feedback. After receiving treatment, the participants' use of discourse markers were assessed through both immediate and delayed post-test. The Result did not show any significant difference between explicit and implicit group.

Toth and Fuentes (2012) compared effects of explicit and implicit instructions on implicit knowledge. Thirty five high school students participated in this study. Explicit group received 270 min of explicit instruction on the Spanish cliticse while control group only practiced the target feature implicitly. Students' knowledge of the target feature was assessed immediately and after six weeks through picture description and audio GJT. Result showed positive effects 
for explicit instruction which confirms permeability of implicit knowledge to explicit instruction (interface).

Maleksabet and Fazilatfar (2014) reviewed the effect of explicit and implicit methods separately and also the effect of these two methods simultaneously. The researchers attempted to determine this effect among various participants in different contexts, and they found that implicit grammar methods had the most effect on learners.

Nazari (2013) investigated the effects of implicit and explicit language instruction on students' ability to learn grammar and use it appropriately in their writing. The results indicated the outperformance of the participants in the explicit group over the performance of the participants in the implicit group in both productive and receptive modes. The findings support the arguments regarding the importance of metalinguistic awareness in language learning.

Rajabi and Dezhkam (2014) investigated the effect of explicit grammar instruction on improving writing accuracy by using four task-focused exercises. The results showed the superiority of the experimental group to the control one, and, in the long run, spotlighted explicit grammar instruction as a scaffolding device that can provide a fertile ground for students to improve writing accuracy.

Fordyce (2014) investigated effects of instructional input and natural input on L2 pragmatics. Eighty one Japanese learners of English were divided into two groups and received instruction on epistemic instance forms. The instruction took about three hours and learners were tested through two writing tasks: descriptive and opinion giving both immediately and four months later. Explicit intervention was found to be significantly more effective than implicit instruction both in short and long terms. However this was true only for the forms that existed in learners' language before instruction took place. For the newly emerged forms, instructional and natural input were found equally effective. Although this study shows superiority of instructional input, tasks used are naturally in favor of explicit knowledge.

Khanbeiki and Abdolmanafi-Rokni (2015) showed that although the participants in the implicit group had progressed during the course, the explicit instruction was the best method in improving participants' pronunciation. The results showed that explicit instruction is better than the implicit instruction.

Eliasi et al. (2013) examined EFL learners' awareness of grammatical structures when they speak spontaneously in group work tasks. The study offered that providing learners with explicit grammar rules can contribute to successful foreign language learning.

Review of literature shows that more research using implicit knowledge measures is required to reach a conclusion on effectiveness of instructional input over natural input. Also interaction between explicit and implicit instruction and different types of linguistic features remains unresolved. 


\section{Macrothink}

\section{Methodology}

\subsection{Participants}

The population of this study was beginner female young children (3-4 years old) in kerman, district 2. In accordance with Dornyie (2007) cluster sampling, all beginner female EFL young children (based on Cambridge Placement Test for young learners) in a kindergarten located in Kerman, district 2 were selected as the sample of this study. They were 40 infants, all female with the age range 3-4 years old. These 40 infants were divided randomly into two groups of 20 control (natural input) and experimental (instructional) one .20 participants $(50 \%)$ were assigned randomly in control and experimental groups.

\subsection{Instruments}

In order to see the relationship between input quality and grammar comprehension and production, the researcher utilized the quantitative research method.The instruments applied in this study were two tests of grammar (Cambridge placement Test for young learners \& a Grammar Test divided to two parts assessing the young learners' grammar comprehension and production).

\subsection{Research Design}

This study was conducted in one of the kindergartens of Kerman (district2), Iran. It was a quantitative experimental study. In this study, the independent variable was input quality, and the dependent variables were grammar comprehension and production of y'oung EFL learners. To see the effect of input quality on young learners' grammar comprehension and production, the researcher utilized the quantitative research method. The instrument applied in this study was a grammar test for young learners divided to two parts of grammar production and comprehension (simple present, present continuous and to be verbs).

The grammar test was given to the students in both control and experimental group (as the pre and post test) with the permission of the kindergarten administer. Cambridge placement test (young learners) was used to homogenize the participants. Based on the Cambridge placement test, the students were homogenized as the beginners, and then they were randomly distributed into two groups of control (natural input) and experimental (instructional) one each containing 20 students. Both groups participated in the study for 20 sessions (one hour and a half each session). Both groups received the same topics during the course considering the same teacher, and the same setting; the only difference was using instructional input in experimental group (language was organized according to the presentation of rules, often given one at a time and in strict sequence. Teacher provided feedback on errors, particularly for violations of rules in the linguistic code. There was limited range of discourse - (IRE) Initiation, response, evaluation (asking, answering, evaluating).

In control group, (learners' errors were rarely corrected, encountered proficient speakers, language events, and had to respond to questions, and were exposed to games, songs, and films). 


\section{Results}

Table 1. Descriptive Statistics of Research Variables in Participants in Pre-test and Post-test

\begin{tabular}{|c|c|c|c|c|c|}
\hline \multirow[t]{4}{*}{ Time } & Group & \multicolumn{2}{|c|}{$\begin{array}{l}\text { Control } \\
(\mathrm{n} 1=20)\end{array}$} & \multicolumn{2}{|c|}{$\begin{array}{l}\text { Experimental } \\
(\mathrm{n} 2=20)\end{array}$} \\
\hline & Statistics Variable & Mean & $\begin{array}{l}\text { Std. } \\
\text { Deviatio } \\
\text { n }\end{array}$ & Mean & $\begin{array}{l}\text { Std. } \\
\text { Deviatio } \\
\text { n }\end{array}$ \\
\hline & Comprehension Score & 0 & 0 & 0 & 0 \\
\hline & Production Score & 0 & 0 & 0 & 0 \\
\hline \multirow[t]{2}{*}{ Posttest } & Comprehension Score & 64.05 & 9.47 & 70.30 & 7.46 \\
\hline & Production Score & 55.15 & 11.66 & 81.75 & 11.48 \\
\hline
\end{tabular}

Table 2. Paired-Sample T Test to Compare Grammar Comprehension Score in Experimental and Control Group in Infants

\begin{tabular}{|c|c|c|c|c|c|c|}
\hline & Comprel & sion Sc & & T-Test & df & P-Value \\
\hline Group & $\begin{array}{l}\text { Total } \\
\text { number }\end{array}$ & Mean & Std.Deviation & \multirow{3}{*}{-2.32} & \multirow{3}{*}{38} & \multirow{3}{*}{0.03} \\
\hline Control & 20 & 64.05 & 9.47 & & & \\
\hline Experimental & 20 & 70.30 & 7.46 & & & \\
\hline
\end{tabular}

Table 3. Paired-Sample T-Test to Compare Grammar Production Score in Experimental and Control Group

\begin{tabular}{|l|l|l|l|l|l|l|}
\hline & \multicolumn{2}{|l|}{ Production Score } & T-Test & df & P-Value \\
\cline { 1 - 5 } Group & $\begin{array}{l}\text { Total } \\
\text { number }\end{array}$ & Mean & Std.Deviation & & & \\
\cline { 1 - 4 } Control & 20 & 55.15 & 11.66 & -7.27 & 38 & \multirow{2}{*}{0.0005} \\
\cline { 1 - 5 } Experimental & 20 & 81.75 & 11.48 & & \\
\hline
\end{tabular}

Table 4. Friedman Test to Rank Post-Test Scores of Comprehension and Production in 
Control Group

\begin{tabular}{|l|l|l|l|l||l|l|}
\hline Score & $\begin{array}{l}\text { Mean } \\
\text { Rank }\end{array}$ & priority & Chi-squire & N & df & P-Value \\
\hline Comprehension Score & 1.90 & The first & \multirow{2}{*}{12.80} & 20 & 1 & 0.0005 \\
\hline Production Score & 1.10 & $2^{\text {nd }}$ & & & \\
\hline
\end{tabular}

Table 5. Friedman Test to Rank Post-Test Scores of Comprehension and Production in Experimental Group

\begin{tabular}{|c|c|c|c|c|c|c|}
\hline Score & $\begin{array}{l}\text { Mean } \\
\text { Rank }\end{array}$ & Priority & Chi-squire & $\mathbf{N}$ & df & P-Value \\
\hline Comprehension Score & 1.05 & $2^{\text {nd }}$ & \multirow{2}{*}{16.20} & \multirow{2}{*}{20} & \multirow{2}{*}{1} & \multirow{2}{*}{0.0005} \\
\hline Production Score & 1.95 & The first & & & & \\
\hline
\end{tabular}

\section{Discussion and Conclusion}

The study was set out to explore the impact of input quality on grammar comprehension and production of young children. The main findings were summarized within results part and this section synthesizes the findings to answer the study's research questions:

1. What is the effect of input quality on grammar comprehension and production of young children in control and experimental group?

2. Which input (instructional or natural) is more effective in second language grammar comprehension and production of young children?

The findings of the study showed that both instructional and natural input facilitates the development of grammar comprehension and production. Further, significant differences exist between the experimental and control group in their grammar comprehension and production. The experimental group (instructional) outperformed the control group (natural) in terms of grammar comprehension, and also outperformed the control group on grammar production. Thus, the observed differences in mean between experimental and control groups can be interpreted as a trustworthy difference that do not fall within the realm of probabilistic sampling variability.

Also comparing the relative effectiveness of instructional and natural types of input, the present study in line with several other studies (Long, 1983; Long ,1988; Ellis 1994, 1997, 2001,\& 200; Norris and Ortega, 2000; DeKeyser, 2000; Doughty, 2003; Spada and Lightbown , 2002; Schneider, 1993; Hunter, 1996; Akakura, 2012 ; Toth and Fuentes , 2012; Nazari, 2013; Rajabi and Dezhkam, 2014; Fordyce, 2014; Khanbeiki and Abdolmanafi-Rokni, 2015 ) found that the instructional input is significantly more effective than natural one. 


\section{Macrothink}

International Journal of English Language Education

ISSN 2325-0887

2016, Vol. 4, No. 1

But this study contradicts those of Long and Robinson,1998; Long and Robinson, 1998; Krashen 1985, 1994 ; Schwartz ,1993; Maleksabet and Fazilatfar ,2014; Norris and Ortega , 2000; Spada and Tomita ,2010; De Graaff ,1997; William and Evans ,1998 ; Housen et al. , 2005; Andringa et al. ,2011.

Evidence from this thesis rejects the idea of Krashen's acquisition/ learning hypothesis that children who are exposed to natural input (acquisition) are better second language acquirers than the ones being exposed to instructional input (learning), it can be concluded that instructional input can help the children to get the grammar better .Children cannot acquire complex morphological and grammatical phenomena so easily because of their undeveloped cognitive ability; therefore, a clear instructional input can work better.

\section{References}

Akakura, M. (2011). Evaluating the effectiveness of explicit instruction on implicit and explicit L2 knowledge. Language Teaching Research, 16(1), 9-37.

Bley - Vroman, R. (1989). 'The logical problem of second language learming' in S.Gass and J.Schachter (Eds),:Linguistic Perspectives on Second Language Acquisition. Cambridge: Cambridge University Press.

Borg, S., \& Burns, A. (2008). Integrating grammar in adult TESOL classrooms. Applied Linguistics, 30(3), 355-388.

Cook, V. (1996). Second Language Learning and Language Teaching, London: Arnold, 1.

Cordr, S. P. (1967). The significance of learners' erros. International Review of Applied Linguistics, 5, 161-170

Corder, S. P. (I997b). "Simple codes" and the source of the learner's initial heuristic hypothesis", Studies in Second Language Acquisition 1: I-Io.

Cullen, R. (1998). Teacher - talk and the classroom context. ELT Jurnal, 52, 179- 87.

DeKeyser, R. M. (2000). The robustness of critical period effects in second language acquisition. Studies in Second Language Acquisition, 22(4), 499-533.

Dornyei, Z. (2007). How to Design and Analyze Surveys in Second Language Acquisition Research. Innovation in Language Learning and Teaching, 1, 153-174

Ebsworth, M., \& Schweers, C. (1997). What researchers say and practitioners do: perspectives on conscious grammar instruction in the ESL classroom. Applied Language Learning, 8(2), 237-259.

Edmondson, W. (1985). Discourse worlds in the classroom and inforeign language. Studies in Second Language Acquisition, 7, 159-68.

Ellis, N. (1994) . Implicit and explicit language learning: An overview. In N. Ellis (Ed.), Implicit and explicit learning of languages (pp. 1-31). London: Academic press. 
Ellis, R. (1994a). The study of second language acquisitio . Oxford: Oxford University press.

Ellis, R. (1994b). 'Second language acquisition research and teacher development: the case of teachers' questions' in D. Li, D. Mahoney, and J. Richards (eds.), Exploring Second Language Teacher Development. Hong Kong: City polytechnic.

Eliss, R. (1994c). A theory of instructed second language acquisition. In N Ellis (ed.), Implicit and Explicit Learning of Languages. San Diego: Academic Press.

Ellis, R. (1997). SLA research and language teaching. Oxford: Oxford University Press.

Ellis, R. (2001a). Investigating Form - Focused Instruction. In Form - Focused Instructional Second Language Learning, edited by R. Ellis. Malden.怕怕 MA:Blackwell.

Ellis, N. C. (2002). Frequency effects in language acquisition: a review with implications for theories of implicit and explicit language acquisition. Studies in Second Language Acquisition, 24.

Ellis, R. (2005). Measuring implicit and explicit knowledge of a second language: A psychometric study. Studies in Second Language Acquisition, 27(2), 140-172.

Ellis, N. (2005). At the Interface: Dynamic Interactions of Explicit and Implicit Language Knowledge. Studies in Second Language Acquisition, 27(2), 305-352.

Ellis, R. (2008). Explicit form -focused instruction and second language acquisition. In B. Spolsky and F. Hult (eds.): The Handbook of Educational Linguistics. Oxford: Blackwell.

Ellis,R., and X. He . (1999). The Roles of Modified Input and Output in the Incidental Acquisition of Word Meaning. Studies in Second Language Acquisition, 21, 285-301.

Fordyce, K. (2014). The differential effects of explicit and implicit instruction on EFL learners' use of epistemic stance. Applied Linguistics, 35(1), 6-28.

Gass, S. (1997a). Input Interaction and the Second Language Learner. Mahwah, N. J.:Lawrence Erlbaum.

Grimshaw, G. M., et al. (1998). First language acquisition in adolesecence: evidence for a critical period for verbal language development. Brain and Language, 63, 237-255

Harmer, J. (2001). The Practice of English Language Teaching (3.ed.). Essex, England: Pearson Education Limited.

Krashen, S. (1981). Second language acquisition and second language learning. Oxford: Pergamon Press. The input hypothesis. London: Longman.

Krashen, S. (1993). The effect of formal grammar teaching: Still peripheral.. TESOL Quarterly, 27, 722-725.

Krashen, S. (1994). The input hypothesis and its rivals. In N. Ellis (ed.) Implicit and Explicit Learning of Languages. London: Academic Press.

Krashen, S. (2003). Explorations in Language Acquisition and Use. The Taipei lectures. 


\section{Macrothink \\ International Journal of English Language Education \\ ISSN 2325-0887 \\ 2016, Vol. 4, No. 1}

Portsmouth, N. H.: Heinemann.

Leeman. J. (2003). Recasts and L2 development: beyond negative evidence. Studies in Second Language Acquisition, 25, 37-63.

Long, M. (1983c). Does second language instruction make a difference? A review of the research. TESOL Quarterly, I7, 359-82.

Long, M. (I988). Instructed interlanguage development. In L.Beebe (ed.),: Issues in Second Language Acquisition: Multiple perspective. New York: Newbury House.

Long, M. (1991). Focus on form: a desing feature in language teching methodology. In k. de Bot, R. Ginsberg, and C. Kramsch (eds.), Foreign Language Research in Cross - cultural perspective, Amsterdam: John Benjamin.

Long, M., \& Robinson, P. (1998). Focus on form: Theory, research and practice. In C. Doughty \& J. Williams (Eds.), Focus on form in classroom second language acquisition (pp. 15-41). Cambridge: Cambridge University Press.

Loshcky, L. (1994). Comprehensible Input and Second Language Acquisition: What Is the Relationship. Studies in Second Language Acquisition, 16, 303-23.

McClure, E. S. (2006). Six Middle School English Language Arts Teachers' Beliefs about Grammar and their Teaching of Grammar while Participating in a Professional Learning Community. Unpublished Dissertation. Atlanta, Georgia: College of Education, Georgia State University. [etd-11122006-225340.]

Norris, J., \& L. Ortega. (2000). Effectiveness of L2 instruction: A research synthesis and quantitative meta-analysis. Language Learning, 50(3), 417-528.

Sanz. C., \& K. Morgan - Short. (2004). Positive evidence versus explicit rule presentation and negative feedback : a computer - assisted study. Language Learning, 54, 35-78.

Schwartz, B. (1993). On explicit and negative data effecting and affecting competence and linguistic behavior. Studies in Second Language Acquisition, 15(2), 147-163.

Schneider, E. (1993). From grammatical competence to grammatically correct performance: An empirical study with regard to the English future tense system. Miami University, $\mathrm{OH}$. (ERIC Document Reproduction Service No. ED 392261).

Toth, P. D., \& P.G. Fuentes. (2012). The impact of instruction on second-language implicit knowledge: Evidence against encapsulation. Applied Psycholinguistics, 31(1), 1-33.د

Trahcy, M., \& L. white. (1993). Positive evidence and preemption in the second language classrom. Studies in second Language Acquisition, 15, 181-204.

Vanpatten, B. (1996). Input processing and Grammar Instruction in Second Language Acquisition. Norwood,N. J.: Ables.

Vygotsky, L. (1986). Thought and Language (Newly revised and edited by A. Kozulin). 


\section{Macrothink}

International Journal of English Language Education

ISSN 2325-0887

2016, Vol. 4, No. 1

Wang, P. (1999). English Grammar Instruction in Taiwan: Student and teacher attitudes. Unpublished thesis. (UMI 9960674).

\section{Copyright Disclaimer}

Copyright for this article is retained by the author(s), with first publication rights granted to the journal.

This is an open-access article distributed under the terms and conditions of the Creative Commons Attribution license (http://creativecommons.org/licenses/by/3.0/). 